\title{
Engineering in vitro models of hepatofibrogenesis
}

Giuseppe Mazza, Walid Al-Akkad and Krista Rombouts.

University College London (UCL), Regenerative Medicine \& Fibrosis Group, Institute for Liver \& Digestive Health, Royal Free Hospital, London, United Kingdom.

Correspondence: Giuseppe Mazza PhD. Royal Free Hospital \& University College London, Institute for Liver \& Digestive Health, Division of Medicine, Rowland Hill Street, London, NW3 2PF, United Kingdom

Phone: +44 02074332794; Fax: +44 02074332852

E-mail: giuseppe.mazza.12@ucl.ac.uk

Correspondence: Krista Rombouts PhD. Royal Free Hospital \& University College London, Institute for Liver \& Digestive Health, Division of Medicine, Rowland Hill Street, London, NW3 2PF, United Kingdom

Phone: +44 02074332794; Fax: +44 02074332852

E-mail: k.rombouts@ucl.ac.uk

Authors disclose no conflict of interest 


\section{ABSTRACT}

Chronic liver disease is a major cause of morbidity and mortality worldwide marked by chronic inflammation and fibrosis/scarring, resulting in end-stage liver disease and its complications. Hepatic stellate cells (HSCs) are a dominant contributor to liver fibrosis by producing excessive extracellular matrix $(\mathrm{ECM})$, irrespective of the underlying disease aetiologies, and for many decades research has focused on the development of a number of anti-fibrotic strategies targeting this cell. Despite major improvements in two-dimensional systems (2D) by using a variety of cell culture models of different complexity, an efficient anti-fibrogenic therapy has yet to be developed. The development of well-defined threedimensional (3D) in vitro models, which mimic ECM structures as found in vivo, have demonstrated the importance of cell-matrix bio-mechanics, the complex interactions between $\underline{\text { HSCs and hepatocytes and other non-parenchymal cells, and this to improve and promote }}$ liver cell-specific functions. Henceforth, refinement of these 3D in vitro models, which reproduce the liver microenvironment, will lead to new objectives and to a possible new era in the search for antifibrogenic compounds.

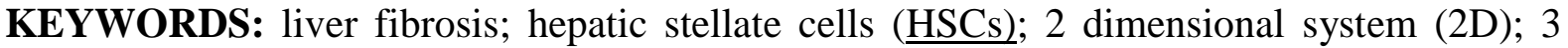
dimensional system (3D); Extracellular Matrix (ECM); organoids/spheroids; Precision-Cut Liver Slices (PCLS); cell sheet stacking; Matrigel/hydrogel, decellularized liver scaffolds 


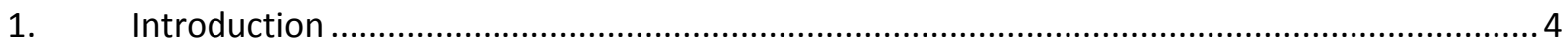

1.1. The liver and pathophysiology ................................................................. 4

1.2. Hepatic stellate cells, ECM producing cells...................................................... 5

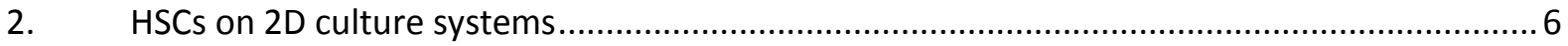

2.1. HSCs interacts with different hepatic cells. ........................................................ 8

2.2. Single cell culture and 2D: importance of adhesion, RGD and matrix components.......9

2.3. HSCs mechanotransduction and biomechanics.............................................. 10

3. Translational medicine and drug discovery: how to proceed ........................................ 12

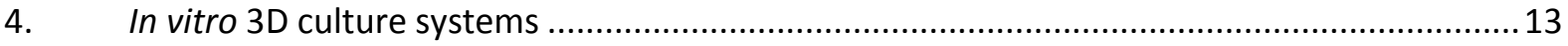

4.1. 3D cell-cell interactions and co-culture systems ............................................ 14

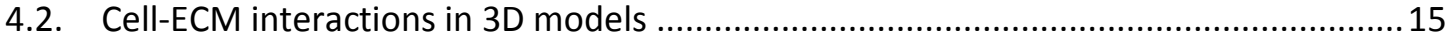

4.3. Tissue architecture and oxygenation in 3D models ......................................... 16

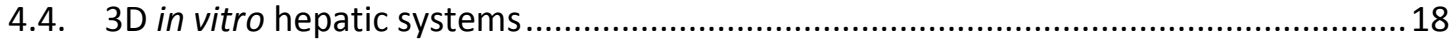

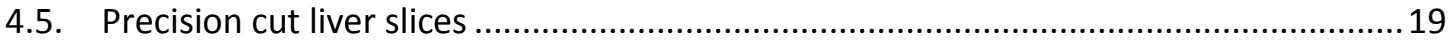

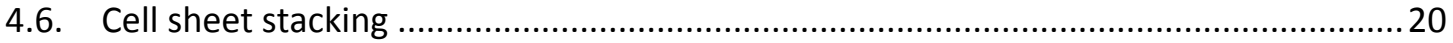

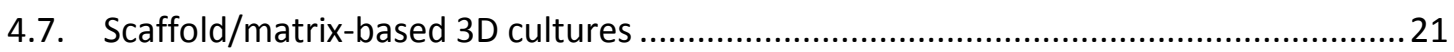

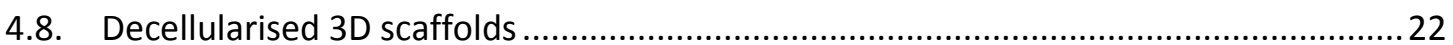

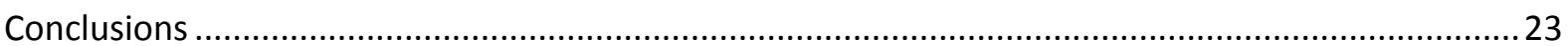

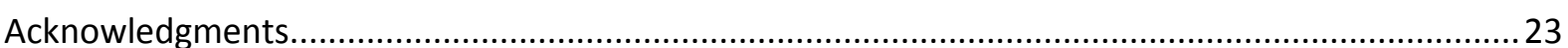




\section{Introduction}

\subsection{The liver and pathophysiology}

The liver metabolises drugs, detoxifies chemicals and produces vital molecules such as blood-clotting proteins and bile, stores energy by accumulating glycogen, and protects the body by neutralizing foreign antigens and microbes from the gut. In order to maintain homeostasis in the organism the liver filters the blood arriving from the digestive tract before it is delivered to the rest of the body. As a secondary lymphoid organ, the liver plays an important role in the immune system and produces acute phase and serum proteins [1]. Alongside the hepatocytes being the parenchymal cells [2], the liver contains nonparenchymal cells (NPCs) such as Liver Sinusoidal Endothelial Cells (LSECs) [3], Hepatic Stellate Cells (HSCs) [4], Kupffer cells [5], Natural Killer cells [6] and different types of immune cells [7, 8]. Each different NPC participates to the liver function and hepatotoxic mechanisms by performing important secondary responses upon hepatocyte damage [9].

Liver fibrosis results from chronic liver injury of different aetiologies. In Western countries, Hepatitis C Virus $(\underline{\mathrm{HCV}})$ infection, Hepatitis B Virus (HBV) infection, certain metabolic liver diseases, hereditary hemochromatosis, porphyria and heavy alcohol intake as well as nonalcoholic fatty liver disease (NAFLD) and its more aggressive form nonalcoholic steatophepatitis (NASH) are all liver diseases which if not treated, lead to chronic injury. Indeed, indifferent from aetiology/cause, and if left untreated will prime the development of liver fibrosis and subsequently cirrhosis [10]. Hence, fibrosis is considered to be a deregulated repair response i.e. woundhealing, characterized by hepatocyte necrosis, inflammation, oxidative stress and excessive ECM deposition which may culminate in cirrhosis. These conditions of end stage liver cirrhosis promotes the perfect microenvironment to develop primary liver cancer i.e. hepatocellular carcinoma (HCC). In fact almost all cases of primary liver cancer are marked by the presence of cirrhosis [11]. 


\subsection{Hepatic stellate cells, ECM producing cells}

In a healthy liver the ECM of the normal perisinusoidal space is made up by a well-balanced and specific quantitative and qualitative amount of collagen type I, III, IV, V and VI, fibronectin, laminin and proteoglycans which has been proven to perform a critical role in maintaining the in vivo phenotype of both hepatocytes and NPCs [12-14]. Hepatic stellate cells are located in the perisinusoidal space of Disse, HSCs adhere to the endothelial cells and make contact with the hepatocytes $[4,15,16]$. Upon liver injury, and especially during chronic liver damage, a dynamic and programmed event occur in which HSCs "transdifferentiate" and become activated by a paracrine stimulation followed by autocrine amplification of the fibrogenic signals $[15,17]$. These events result in a complex and bidirectional signalling network between different cell types and their mediators leading to the accumulation of ECM proteins and hepatic fibrosis $[18,19]$. Moreover, fibrogenic hepatic myofibroblasts predominantly arise from liver resident HSCs [20, 21], thus a major player in ECM modification during acute and chronic liver injury are activated HSCs. Rather than an uncontrolled, continuous process of ECM secretion and deposition, hepatic fibrosis is characterized by a shift in the balance between deposition and degradation due to changes in matrix metalloproteinases (MMPs) and their inhibitors i.e. the tissue inhibitor of MMPs (TIMPs) [12, 22-24]. Therefore, already activated by the initial stimulus, HSCs express and secrete higher levels of fibrillar collagens type I, II and III, thus forming thick and highly cross-linked collagen bundles. As a result, this interrupts the normal fine balance from a collagen type IV laminin-rich low-density basement membrane-like structure into a remodelled collagen type I and III-rich fibrillar matrix [25-29]. These changes in collagen production can become so dramatic that the total content of collagens and the noncollagenous components increases 3 - to 5-fold, indicating that the 3 dimensional (3D) network formed by the ECM in the space of Disse is a very dynamic phenomenon [14]. 
Furthermore, these changes in hepatic ECM are correlated with specific ECM serum concentrations [29-31].

In the past decades, several approaches to isolate HSCs have been used that include; density gradient separation, fluorescent cell sorting and explant culture [4]. The method to separate HSCs from other hepatic cells is based on employing an ex-vivo enzymatic digestion of the liver tissue by collagenases, pronases and DNase allowing for the dissociation of the hepatic cells from the surrounding ECM [32-34]. This can be followed by several centrifugation steps and a refined multistep or single step gradient centrifugation or flow cytometry/FACS analysis. Freshly isolated HSCs are presented with prominent dendritic cytoplasmic processes and retinoids containing lipid droplets. The cells will gradually display a slightly more myofibroblast phenotype marked by heterogeneous retinoid droplet size during the following days in culture $[4,35,36]$. Henceforth over several decades, many in vitro investigations have demonstrated the remarkable cell plasticity of HSCs that not only reflects various phenotypes but also mirrors different functions.

\section{HSCs on 2D culture systems}

In general, over the last 5 decades the most described and used model to investigate cell biology/behaviour is the traditional $2 \mathrm{D}$ monolayer culture where investigators culture the cells on stiff and flat polystyrene dishes. Additionally, in the field of liver cell biology, investigators have used this model to explore HSCs biology. By using non-coated plastic cultures in the presence of foetal bovine serum, observations were made that when culturing primary quiescent HSCs, obtained from a healthy liver, cells spontaneously "transdifferentiate" into an activated myofibroblast-like cell, characteristic of a diseased liver. Therefore, this system represented for many years an in vitro culture model to compare quiescent healthy cells versus activated cells present in the diseased liver. 
The definition of the HSCs "activation" refers to the conversion of a resting vitamin A-rich cell into a cell type which was characterized by proliferation, fibrogenesis and being highly contractile as was observed in 2D flat un-coated polystyrene dishes [14, 37]. This single mono culture of quiescent HSCs has demonstrated alterations in important proteins and genes during HSCs activation in vitro. Moreover, drug treatment of culture-activated HSCs showed to inhibit or to reverse this activated HSCs phenotype by inhibiting ECM de novo synthesis, proliferation and contraction [38-41]. Limitations in this experimental set-up and differences between in vitro culture activation and in vivo activation were first demonstrated by comparing activated HSCs isolated from fibrosis-induced rodents injected with carbon

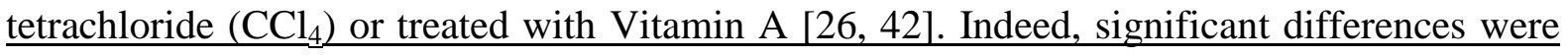
demonstrated in HSCs lipid droplets accumulation, proliferation rate, and very important, alterations in the ratio of collagen type I to type III produced by $\mathrm{HSCs}$ from $\mathrm{CCl}_{4}$ was enhanced as compared with control rats. In addition, HSCs proliferation strongly increased when cells were co-cultured with Kupffer cells isolated from $\mathrm{CCl}_{4}$ treated animals in comparison to Kupffer cells isolated from control animals [26, 42]. Differences were observed between HSCs phenotypes i.e. in vitro culture activated HSCs versus in vivo activated HSCs obtained from $\mathrm{CCl}_{4}$ and BDL induced activated HSCs. Deminics et al., employed mouse microarray analysis and demonstrated that various genes were differently affected depending on the model used such as genes involved in proliferation (Ki 67), cell survival (survivin, septin 4), cytoskeletal organization and contraction (plexin C1, anillin, leiomodin), inflammation (CXCL14, osteopontin), ECM organization and degradation $\underline{\text { (Col8a1, MMP10), and lipid metabolism (cholesterol 25-hydroxylase) as well as transcription }}$ factors (PRX1, LMCD1), cell surface receptors (adenosine receptor 2b, GPR91), bone morphogenetic protein BMP5, and neural markers (synaptotagmin, neurotrimin) $[35,43,44]$. Furthermore, gene expression microarray analysis and proteomics showed a clear difference 
between in vitro-activated and in vivo-activated HSCs. In addition, data showed that when cells were isolated at various time points after cessation of injury i.e. after recovery, cells were characterized by diminished expression of activated HSCs markers, but stayed primed $[35,45-47]$. Overall, these data indicate that the in vivo-activated HSCs may reflect more the influence of the specific microenvironment on their behaviour in the fibrotic liver which favour the use of in vivo-activated HSCs isolated from a fibrotic liver over in vitro culture activated HSCs isolated from a healthy liver when exploring new antifibrotic targets and drugs.

\subsection{HSCs interacts with different hepatic cells.}

Co-culture systems have been used to explore the intercellular communication between HSCs and other hepatic cells. Liver fibrogenesis is sustained and modulated by an intense cross-talk between different hepatic cell populations that involves the synthesis and release of several mediators, including growth factors, cytokines, chemokines, reactive oxygen species, adipokines, vasoactive agents and plasma proteins. Cell-cell interactions have been investigated by co-culturing cells in direct contact with one and another to measure overall changes in gene/protein expression as well as functional changes for example induction in proliferation and migration. Indeed, many experiments in $2 \mathrm{D}$ culture systems have shown a clear interaction i.e. cross-talk between HSC and Kupffer [48], hepatocytes [49], liver sinusoidal endothelial cells (LSEC) [3] cholangiocytes [50] and HCC [51] as well as with platelets [52], and with cells of the immune system [53-55]. This approach does not discriminate between the effects of one cell type vs the other cell type, but identifies the overall effect of growing the cells together. Only in the context of non-adherent immune cells 
in co-culture with HSCs one can wash away the immune cells after incubation and measure specific functional and specific changes in gene/protein expression of HSCs. Indirect cocultures can be established by using transwell inserts, to separate both cell types, but permits access of secreted factors to affect genes or proteins in both cell types of interest. To obtain a clear readout of how one cell type can affect the cell behaviour of HSCs one can measure the direct paracrine effect by culturing the HSCs with the conditioned medium of the other cell type. This conditioned medium contains all cytokines, growth factors/soluble factors, exosomes, microparticles and lysosomes produced and secreted by the hepatic cell $[42,56-$ 58]. Furthermore, activated HSCs secrete cytokines and growth factors that can stimulate the growth, proliferation, and migration of cancer cells, as well as other non-neoplastic cells within the liver tumour stroma. This was demonstrated by exposing cancer cells to the conditioned medium collected from activated HSCs and vice versa [51, 59-62]. Investigating the content of the conditioned medium will identify possible key players/mechanisms and their functions during the cross talk between HSCs and other hepatic cells [44].

\subsection{Single cell culture and 2D: importance of adhesion, RGD and matrix components}

Many studies have demonstrated the involvement of important signalling pathways in cellular adhesion processes which also differ when HSCs are grown on plastic, collagen or cultured on ECM [63-65]. These obtained advances to control the ECM composition have facilitated those studies that explain the spatial distribution of integrin-mediated adhesion, cellular function, polarity and proliferation [66]. Several ECM proteins activate integrins through different mechanisms, resulting in the integration of multiple signalling pathways and thus different cellular behaviours. In fact, cells assume a specific morphology based on integrin- 
mediated adhesions to the extracellular matrix, this is observed when comparing cells on a flat surface, where adhesion occurs on one plane of the cell, to those cultured in a 3D microenvironment, where adhesion occurs on all planes (Figure 1).

Moreover, Chen et al., have discovered a new role for integrins in mediating HSCs-derived exosomes, in which these exosomes bind to neighbouring HSCs which in turn alters the profibrogenic exosome-regulated functions in these HSCs [67]. From the chemical point of view, ECM proteins containing an Arg-Gly-Asp (RGD) sequence are known to alter cell functions. Indeed, the most basic biological functionality in using 2D cultures in combination with ECM is achieved by addition of cell-adhesive ligands, commonly used RGD peptides. For example, fibronectin is an ECM protein with this specific peptide sequence, RGD that alters cellular attachment and spreading, as well as cell integration properties [68]. Until today, the RGD peptide is a major adhesive domain of several ECM components, such as that involved in the binding of fibronectin [69], an important assembler of the collagen matrix to the alpha5beta1 integrin receptor [70] with the presence of intra-molecular RGD motif in collagen [71].

\subsection{HSCs mechanotransduction and biomechanics}

As mentioned before, several in-depth studies have shown that during the process of chronic liver disease, changes in specific protein families of the ECM such as collagens, laminins and integrins give rise to the formation of new and specific networks with their specific ligands and receptors. For example, collagen is the most abundant component of scaffolding ECM in tissue stroma and is essential for the macromolecular structure [72]. Moreover, collagenmediated ECM networks have a strong effect on biological properties such as matrix/tissue stiffness and therefore tissue/organ structure. These events add up to the complexity of the ECM microenvironment that forms a support for the intrinsic communication between cells as well as functioning as a reservoir for the secreted growth factors, cytokines, exosomes and 
matricellular proteins during liver injury. This further indicates that the liver is a viscoelastic tissue with increasing liver stiffness during the development of fibrosis.

Hepatic stellate cells which are also anchorage-dependent cells, will sense the mechanics of their surroundings by pushing and pulling on the ECM, and will therefore change intracellular signals and cellular behaviour (Figure 1) [44, 73, 74]. Hence, investigating the mechanotransduction phenomenon and its effect on the HSCs phenotype has led to the observations that depending on the hardness of the substrates used i.e. soft versuss stiff, the quiescent phenotype of HSCs will be maintained or they will transform into activated myofibroblasts. For example, mechanical stretch enhances TGF- $\beta$ expression on mRNA and protein levels in HSCs [75] and induces epithelial to mesenchymal transition (EMT) [76]. Rat HSCs exposed to static water pressure $(10 \mathrm{mmHg}, 1 \mathrm{~h})$ undergo increased proliferation and migration [77], whereas targeting of the mechano-sensitive nuclear factor Yes-Associated Protein (YAP) $[78,79]$ and Bromodomain-containing protein 4 (BRD4) $[80,81]$ reversed liver fibrosis [82]. These in vitro studies comparing HSCs cell behaviour under different biomechanical conditions are important to understand the complexity between HSCs and their liver ECM microenvironment in healthy liver versus diseased liver [83]. Although all observations made in 2D single culture, whether on plastic culture dishes or ECM matrix components, these in vitro models are still limited. If stiffness is affecting cell behaviour than the mechanical heterogeneity, which is typically found in healthy and diseased liver, is absent in the 2D culture models. Indeed, Desai et al. demonstrated that healthy livers are mechanically heterogeneous with portal tracts being stiffer than the pericentral regions, which suggest that cells in distinct regions of the liver can be exposed to mechanically distinct microenvironments [84]. Therefore, culturing HSCs on collagen in 2D does not recapitulate the cellular and genetic behaviour of the HSCs present in a healthy liver or the fibrous septa/liver nodules during the process of progressive liver fibrosis. As a consequence, 
reductionist 2D monolayer cell culture systems with collagen or ECM substrates do not address fully the complex multicellular processes that give shape to the healthy or fibrotic liver tissue. Thus, one of the major drawbacks of using traditional 2D cultures to model living systems is inaccurately reflecting the physiological manner in which modulators, nutrients, oxygen, and metabolites are applied and removed.

\section{Translational medicine and drug discovery: how to proceed}

Over the past few decades, the invention of new efficient drugs for the treatment of liver disease has been hampered by the lack of robust and biologically relevant hepatic models, where functional pharmacokinetics and toxicological studies can be investigated [85-87]. For example, limitations of these in vitro culture systems are related to a fast decline in hepatocyte-specific functions, dedifferentiation and loss of hepatocyte polarity after short term culture $[88,89]$. Furthermore, no efficient anti-fibrogenic therapy has been developed yet. Possible anti-fibrogenic effects of compounds were tested in 2D models and further extrapolated into in vivo models $[10,90,91]$. In many cases, drug candidates that showed efficacy when tested in different 2D in vitro systems did not reproduce similar successful effectiveness in vivo animal models, leading to misinterpretation of the data [92-94]. For many years, animal models have played an essential role in the process of developing drug compounds. This is because animal models combine the native ECM microenvironment, different cell types, as well as oxygen and nutritional flows [95, 96]. Limitations of using animal models are numerous; such as the non-human origin, significant differences in metabolic capacities, cytochrome $\mathrm{P} 450$ isoforms activity, interspecies physiologies, drug bioavailability and half-life, and disease adaptive mechanisms [97-100]. Many of these compounds fail due to undesirable toxicity and/or lack of clinical effectiveness, which is usually observed during the most expensive phase of clinical development i.e. phase III [86, 
94]. Indeed, a staggering 9 out of 10 drugs that passed animal trials ended up failing human clinical trials [100-105]. To reduce the overall cost of liver disease drug development, ineffective or very toxic compounds/molecules should be excluded as soon as possible, preferably before animal testing takes place. Any valid system for drug testing implicates the consideration of both toxicity and efficacy, which in most cases are organ/tissue and cellspecific. Therefore, in vitro tissue-specific models are necessary for the accurate prediction of the safety and functional drug dosage which would be suitable for High Throughput Screening [106-108]. One obvious solution would be using 3 dimensional models which can represent human tissue as much as possible by improving the structural support for cells, contributing to the mechanical properties of the tissue (rigidity / stiffness) and providing a flexible physical environment to allow remodelling in response to tissue dynamic processes such as wound healing. The only 3D model that would reflect the many aspects of the hepatic ECM is the liver ECM itself (Figure 2) as besides the aforementioned need for a 3D environment the ECM of the liver is known to provide bioactive cues for the cells to respond to the microenvironment as well as acting as a reservoir for growth factors which locally potentiates the cellular actions.

\section{In vitro 3D culture systems}

It is becoming clear that creating the liver microenvironment with its cell-matrix interactions, cell-cell adhesion and cellular signalling is difficult but is essential for liver studies. As mentioned before, traditional 2D cell culture systems have proven to be valid in investigating possible mechanisms of cell behaviour and for drug screening but have limitations in maintaining cell behaviour as observed in a 3D microenvironment (Table 1). Henceforth, 
efforts have been made to develop well-defined $3 \mathrm{D}$ in vitro models which mimic ECM structures as found in vivo. These studies could provide several benefits such as simulating the liver physiology under an in vivo-like microenvironment thus enhancing liver functionality, constructing complex microscale ultra-structures which are the most critical criterion in liver tissue engineering. This can provide a rapid, easy and high-throughput screening process using a small number of human cells. Moreover, a critical factor for promoting liver cell-specific functions in vitro is the co-culturing of hepatocytes with nonparenchymal cells either in direct contact or via paracrine stimulation in these newly developed in vitro systems [49, 109].

\subsection{D cell-cell interactions and co-culture systems}

Differentiation, migration and proliferation are key cellular functions strongly regulated by signals from other cells [110]. Therefore, an ideal in vitro model needs to resemble tissue specific cell-cell interactions to improve drug screening outcomes. Three dimensional culture systems enable the establishment of platforms in which cell-cell interactions can be fully investigated within the 3D microenvironment $[109,111]$. The morphology and spatial organization maintained within 3D culture systems allow for preservation of natural adhesion between cells as this process is primarily mediated by cadherin proteins. Besides their organizational role, cadherins transduce mechanical signals within the cells which in turn regulate gene expression signalling pathways [112]. Therefore, key signalling pathways are maintained in $3 \mathrm{D}$ cultures and better resemble the in vivo scenario when compared to $2 \mathrm{D}$ systems. For example, the nuclear factor YAP has shown to be a critical driver of HSCs activation and screening for YAP inhibitors in 3D spheroids could present a novel approach for the treatment of liver fibrosis [79]. Furthermore, cellular heterogeneity is an essential 
feature of all tissues and therefore it is crucial to recapitulate the interactions between different cell types in order to reproduce the in vivo complexity thus enabling a full assessment of key molecular pathways in vitro [113, 114]. In fact, several studies have demonstrated a superior correlation in in vivo cellular phenotype by employing co-cultures rather than monoculture systems. For instance, experiments employing 3D cultures with hepatocytes have demonstrated that 3D co-cultures of hepatocytes with HSCs favours several hepatocyte functions such as engraftment, proliferation and differentiation due to the secretion of soluble factors produced by HSCs [115-117]. Moreover, studies have shown that the ECM-producing stromal cells in primary liver cancer have a dynamic and flexible function in tumour development, which in turn can regulate the response of cancer cells to chemotherapy. High collagen content is a key barrier for interstitial drug penetration among ECM-related proteins and thereby reduces the efficacy of chemotherapeutics. Thus major efforts have been made using, for example, co-cultures of HSCs and hepatocytes/HCC cell lines in multicellular tumour spheroid models to investigate the complex signalling cascade between different cell types during liver diseases [118-122]. Furthermore, by using hepatic organoids it was shown that the fast and spontaneous activation of HSCs, as observed in 2D cultures on plastic, was prevented as a quiescent-like phenotype was maintained for 21 days in culture. In addition, HSCs retained their capacity to respond to pro-fibrotic compounds directly and in a hepatocyte-dependent manner [123].

\subsection{Cell-ECM interactions in $3 D$ models}

The interaction between ECM proteins and cellular receptors affect different physiological and pathological processes $[124,125]$. These interactions lead to a series of chemical and mechanical stimuli which may affect the phenotype and function of both the ECM and cells 
$[126,127]$. Therefore, recreating tissue-specific human ECM, both composition and architecture, represents an area of research actively pursued in medicine and biology for improving the quality and validity of data generated from in vitro cultures. For example, integrins act as transmembrane receptors that play a key role in mediating the interactions between cells and the ECM. To do so, integrins physically connect ECM receptors with cell membranes and the nucleus through a cascade of signalling pathways, thus regulating cellular mechanisms in response to environmental stimuli [128] by affecting various cellular functions [129]. Moreover, integrins are able to sense changes in ECM biomechanical properties during liver fibrosis/cirrhosis and cancer development [83, 130-132], which may affect integrin-dependent signalling pathways [133]. This has been demonstrated by emphasizing the significant differences in signalling pathways in cells cultured on 2D and in 3D models leading to different cell response after drug treatments [126, 134-136].

\subsection{Tissue architecture and oxygenation in 3D models}

Tissue architecture and topography have been shown to orchestrate many cellular functions such as cell morphology, differentiation, polarization and gene expression [73, 84, 137]. Therefore, the development of 3D culture models needs to mimic the spatial organizational complexity of human tissues. This requests resembling the cellular interaction with ECM proteins, which is mediated through the binding of both apical and basal membranes with layers of the structural ECM proteins. Unfortunately, these bi-directional interactions are absent or disrupted in many 2D models [108]. Oxygenation or gradients in oxygenation are key for appropriate cell behaviour and are neither achievable nor considered in 2D culture systems. The only way of achieving or investigating the effect of oxygenation is by analysing the effect of hypoxia which is a key regulator in the activation of HSCs and is accomplished by growing cells in strictly controlled hypoxic conditions $\left(3 \% \mathrm{O}_{2}\right)[18,138,139]$. Therefore, 
it is critical in the design of $3 \mathrm{D}$ in vitro platforms to mimic the tissue-specific oxygen and nutrient gradients in order to satisfy the tissue-specific metabolic request. In recreating the optimal oxygen gradient characteristically present in biological tissue it is important to consider that the maximum distance between a cell and a vessel is between 150 and $200 \mu \mathrm{m}$ in vivo [140, 141]. Lack of regulation in oxygen levels will lead to alterations in key cellular functions such as cell proliferation and metabolism [142]. Regulation of oxygenation can be achieved by using perfused 3D models, "microphysiological systems" or "organs on chips". These systems use microfluidic or microscale reactors to control the flow of culture medium. For example the LiverChip comprises a scaffold that fosters formation of an array of $\sim 0.2-$ mm 3D-tissue structure with primary human hepatocytes, HSCs and Kupffer cells, and an onboard microfluidic pumping system. Each well/scaffold is individually perfused and the constant recirculation maintains/enhances cell viability, cellular function and ensures adequate oxygenation. Thus, this dynamic system precisely perfuses the scaffold with culture medium to control oxygenation and shear stress on the tissue, enabling long-term culture with retention of physiological responses [143-145]. These perfused systems, are often better characterized and controllable than static cultures concerning the direct surrounding of tissues thus introducing well-characterized medium flow rates around the tissues allow the cell $\underline{\text { secretions to mix with the rich medium through perfusion. Moreover, new developments in }}$ multi-organ chip (MOC)-based systems combine the benefits of a controlled medium flow around the different engineered tissues with interconnections to demonstrate cross talk between the organs creating a "human-on-a-chip," a whole body biomimetic device. These clusters of assembled cells mimic how organs in the body function, both separately and in $\underline{\text { tandem. }}$ 


\section{4. $3 D$ in vitro hepatic systems}

Advanced 3D liver models have been established by employing cell spheroids, cell sheets or scaffold-based 3D-cultures aimed at recreating the physiological and pathological hepatic microenvironment [146]. Given the structural diversity of the extracellular environment in vivo i.e. healthy liver versus diseased liver, it is not surprising that research towards a more in vivo-like system is wanted $[147,148]$. Thus, major efforts have been made to mimic the in vivo HSCs-hepatic cell and HSCs-ECM interactions. Indeed, it has been demonstrated that the behaviour of HSCs is regulated by a 3D ECM [149-152]. Freshly isolated HSCs showed changes in cell morphology and cellular functions when comparisons were made between 2D plastic cultures and culturing cells in thick matrigel, 3D type I collagen gel or other substrates $[4,151]$. Henceforth, many different approaches have provided valid information concerning the co-culture of parenchymal cells with HSCs. For example the paracrine effect of rat HSCs on primary hepatocytes was investigated by using a spheroid-based 3D culture. A chip was created with a "cascade" design in which the HSCs culture medium flowed towards the hepatocytes cultured in 3D-spheroids. This enabled the separate investigation of HSCs and hepatocyte specific functions over a short period of time [109]. The 3D-Spheroids system also allows the development of 3D hepatocyte cultures and in fact was one of the first models developed [153]. The hepatocytes grown in 3D spheroids form multicellular clusters that produce ECM allowing for cell-ECM and cell-cell interactions [154, 155]. This has proven to preserve hepatic-specific functions and differentiation when compared with $2 \mathrm{D}$ culture systems [156]. Thus the 3D spheroids allow the study of drug pharmacokinetics and toxicity in order to identify the most appropriate dose [157]. Limitations of this system include the variability of the spheroid size i.e. data reproducibility during drug efficacy and toxicity studies and assembly time of the 3D spheroids [154]. In contrast, by using micromold-based procedures, uniform microsized spheroids can be produced and are typically small enough 
$(<100 \mu \mathrm{m}$ diameter $)$ to ensure good diffusion of oxygen and nutrients. These spheroids can also be used as building blocks to create larger organoids [158]. Another system takes the advantage of inoculating primary hepatocytes into a pre-established non-parenchymal cell culture grown on 3D nylon scaffolds. This approach allows a culturing time for up to 3 months while maintaining important hepatic functions [49]. Furthermore, the Scar-in-a-Jar 3D model is based on culturing fibroblasts with addition of neutral or charged macromolecules [159] that may provide a new pathophysiological relevant in vitro screening assay. This system analyses antifibrotic lead compounds which specifically target the collagen biosynthesis. This system favours collagen protein synthesis and secretion when compared to traditional 2D plastic culture dishes [160]. Although, whether the profibrogenic cell behaviour of the HSCs and more specifically the screening of antifibrogenic compounds will render this system favourable has yet to be proven. All systems described contain several limitations such as the presence of a standardised matrix stiffness and a uniform topography $[161,162]$ which are likely two major variables that greatly contribute to an altered HSCs phenotype in different liver diseases, thereby changing HSCs cell behaviour.

\subsection{Precision cut liver slices}

Precision-Cut Liver Slices (PCLS) is a 3D in vitro model to study HSCs in a system that closely reflects the in vivo situation with maintaining the intact hepatic architecture and cellular heterogeneity [161]. This 3D system can be obtained from different species such as rat [163], mouse [164] and human liver $[165,166][167,168]$. The liver slices are $8 \mathrm{~mm}$ in diameter, $250 \mu \mathrm{m}$ thick and contain 70 to 100 lobules. They are maintained in a vial that is set on a roller platform and gently agitated at 37 degrees Celsius, with $5 \% \mathrm{CO}_{2}$ and $40 \% \mathrm{O}_{2}$ in a humidified incubator. This set up allows performing experiments over a time period of 24 hours to 1 week [169-171], although, this short incubation time might be considered a major 
drawback of this system. Furthermore, proteomics analysis has shown to give different outcomes depending on the species investigated $[164,166]$. On the other hand, by using this 3D in vitro model the cellular behaviour of hepatocytes and all non-parenchymal cells in the native ECM microenvironment can be investigated [168, 172].

\subsection{Cell sheet stacking}

Cell sheet engineering is a unique scaffold-free tissue-engineering approach that uses poly $(\mathrm{N}-$ isopropylacrylamide) (PNIPAAm)-grafted, temperature-responsive culture dishes (TRCDs). The temperature-responsive culture surface can be developed by implanting a temperatureresponsive PIPAAm gel into a standard tissue culture polystyrene dish. This material alternates between hydrophobicity and hydrophilicity based on the working temperatures, which further affects the capability of the cells to attach to the material. Indeed, at low temperature $\left(20^{\circ} \mathrm{C}\right)$ the surface of the material becomes hydrophilic and cells cannot attach. In contrast, at $37^{\circ} \mathrm{C}$ the shell turns hydrophobic and cells can attach and proliferate on the surface. Thus, cells expanded on the surface can be harvested without enzymatic treatment (e.g trypsin) but simply by reducing the temperature. Interestingly, the interaction between cells remained preserved and several layers of cell sheets can be assembled together in order to build more complex 3D structures $[173,174]$. Notably, hepatic cell sheets have been produced by using both parenchymal and non-parenchymal cells and this system enhanced hepatic functions such as albumin and urea synthesis compared to 2D monolayer cultures $[146,175]$. Nevertheless, due to absence of vascularisation and therefore oxygen supply, the hepatocyte cell sheet system can only be used for a short period of time because of the

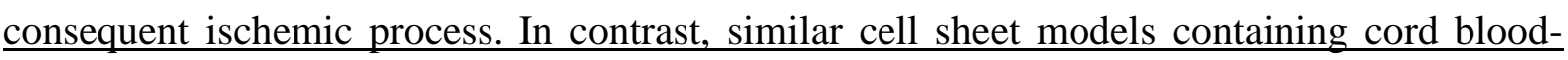
derived endothelial colony-forming cells (ECFCs), sandwiched with fibroblasts sheets, 
recreated prevascularised 3D cell-dense tissue constructs and formed functional microvessels after 1 week of transplantation in vivo [173].

\subsection{Scaffold/matrix-based 3D cultures}

One of the most exploited systems for the development of 3D in vitro culture platform consists of reseeded cells in 3D scaffolds. These scaffolds can be made of synthetic or derived from biological sources. Synthetic scaffolds can easily be manufactured but lack key features such as physiological bioactivity, biomechanics and accurate microarchitecture. The most common artificial matrices employed for engineering biological tissue are synthetic polymers (e.g. polylactide-co-glycolide (PLG), Polyethylene glycol (PEG)), polycaprolactone (PLA) [176] [177] and naturally-derived hydrogels (e.g., alginates, celluloses, polyethylene) [178], respectively [179-181].

In addition, 3D scaffolds can be developed from biological ECM-derived material. For instance, several substrates have employed basement membrane or type I collagen gels. These materials are characterized by the preservation of ECM molecules that improve cell attachment and differentiation. Several limitations mark these biological gels, as it is difficult to obtain batches of gels marked by homogenous mechanical properties $[179,180]$ and these gels do not resemble natural 3D tissue-microarchitecture. Therefore cells encapsulated in these gels randomly self-organize into a non-physiological 3D structure. Moreover, these materials are often not tissue-specific thereby affecting the reproduction and maintenance of specific liver metabolic function [181]. To overcome this limitation, the development of human ECM hydrogel with retained ECM protein composition using lyophilized decellularized tissue should provide the most optimal physiological microenvironment for cell culture in order to promote survival and proliferation of hepatic cells [182]. 


\subsection{Decellularised 3D scaffolds}

Over the past few decades, several studies have demonstrated the suitability of using decellularized human or animal tissue by employing naturally occurring ECM scaffolds for tissue engineering [183-188]. In this context, liver bioengineering has the potential to be utilised for transplantation and as $3 \mathrm{D}$ in vitro cultures for toxicity testing during preclinical drug development. There is indeed convincing experimental evidence that "DecellularisationRecellularisation" technologies provide a valuable platform for liver bioengineering through the repopulation of a liver ECM scaffold with appropriate parenchymal and non-parenchymal liver cells $[189,190]$. Moreover, decellularisation protocols need to be tissue-specific due to the high variability of ECM protein compositions between different types of tissue [191], as well as disease-specific [190, 192, 193] and species-specific, in order to recapitulate the human pathophysiological 3D environment. Some limitations with other 3D platforms have been overcome by using decellularised hepatic tissue. Hepatic function of primary HSCs has been maintained in vitro for 3 weeks. Additionally, preservation of the vessels within the decellularised hepatic tissue has been achieved, including re-endothelialisation of the vessels with human umbilical vein endothelial cells (HUVECs) in vitro and neoangiogenesis in vivo [194, 195]. Furthermore, Yang et al. have demonstrated the preservation of bioactive factors, such as bFGF, PDGF and VEGF, within the decellularised tissue [196]. However, limitations of decellularised tissue scaffolds include availability of healthy human liver tissue and access to diseased liver tissue. 


\section{Conclusions}

Despite all the major improvements in refining the isolation methods and culture conditions in $2 \mathrm{D}$ and $3 \mathrm{D}$, there is no efficient antifibrogenic therapy available [10, 90]. Many promising compounds fail when translated from $2 \mathrm{D}$ in vitro cultures to in vivo models owing to the lack of liver specific microenvironment. The absence of physiological, routine and easy to perform 3D in vitro screening assays slowdown or halt further investigation of possible lead compounds before they can be tested in animal models or commencement of phase I clinical trials. Overall, the optimization of these in vitro models will lead to new objectives and to a possible new era in the search for antifibrogenic compounds.

Furthermore improvements in in vitro culture models which more closely reflect the liver microenvironment need to be investigated. Therefore research efforts continue to optimize 3D biosystems composed of single and/or co-culture platforms. In this aspect, HSCs showed to be very important as secondary supportive or stromal cells to obtain a heterotypic interaction between the parenchymal cells. Indeed, non-parenchymal cells such as HSCs increase the viability and functionality of hepatocytes in the 3D biosystems, made of synthetic and biological-derived materials $[117,197,198]$. Finally, it will be paramount to design a routine $3 \mathrm{D}$ cell culture system for researchers in both academia and the pharmaceutical industry.

\section{Acknowledgments}

G.M. is supported by the British Research Council (BRC) and W.A.A is funded by The Royal Free and Fiorina Charity. Funding is from the Royal Free Charity, NIHR UCLH BRC and Innovate UK (KR). 


\section{Figure Legends}

Figure 1. Key differences in 2D and 3D support systems which affect HSCs behaviour and therefore drug screening. Culturing HSCs on 2D plastic culture dishes deprived of important ECM-specific bioactive cues, with a stiffness of more than $2 \mathrm{GPa}$, has a major impact on cell morphology with cell-cell interactions only on the $x-y$ plane. When HSCs are grown on a hand-made scaffold stiffness can be chosen $(1-20 \mathrm{kPa})$. In this 3D microenvironment the HSCs cell body is in contact with the surrounding 3D microenvironment and cell-cell interactions are present on all planes.

Figure 2. Schematic overview of different systems, with advantages and disadvantages, for culturing HSCs in vitro. Growing freshly isolated HSCs obtained from a healthy liver in 2D cell cultures allows to study the HSCs transdifferentiation into in vitro activated HSC. Culturing HSCs in 3D cultures favours the study of HSCs cell behaviour in the 3 dimensional $\underline{\text { microenvironment and the interaction with other hepatic cells. Precision-Cut Liver Slices is a }}$ 3D in vitro model to study HSCs in a system that closely reflects the in vivo situation with maintaining the intact hepatic architecture and cellular heterogeneity. Repopulation of HSCs in 3D human liver acellular scaffolds favours the study of HSCs biology as the scaffolds maintains the ECM protein composition, 3D-architecture and physicochemical properties of the native tissue.

Table 1. Comparison of limitations and strengths of classical cell culture techniques with recently developed 3D culture systems specific for modelling diseases in which tissue remodelling is a key factor in disease progression such as for example fibrosis and cancer. 


\section{$\underline{\text { References }}$}

[1] A.J. Macpherson, M. Heikenwalder, S.C. Ganal-Vonarburg, The Liver at the Nexus of HostMicrobial Interactions, Cell Host Microbe, 20 (2016) 561-571.

[2] A. Treyer, A. Musch, Hepatocyte polarity, Compr Physiol, 3 (2013) 243-287.

[3] G. Marrone, V.H. Shah, J. Gracia-Sancho, Sinusoidal communication in liver fibrosis and regeneration, Journal of hepatology, 65 (2016) 608-617.

[4] K. Rombouts, Hepatic Stellate Cell Culture Models, in: G.C.R.a.P. M (Ed.) Stellate Cells in Health and Disease, Academic Press Elsevier2015, pp. 15-27.

[5] B. Gao, W.I. Jeong, Z. Tian, Liver: An organ with predominant innate immunity, Hepatology, 47 (2008) 729-736.

[6] Z. Tian, Y. Chen, B. Gao, Natural killer cells in liver disease, Hepatology, 57 (2013) 1654-1662.

[7] R. Fahrner, F. Dondorf, M. Ardelt, U. Settmacher, F. Rauchfuss, Role of NK, NKT cells and macrophages in liver transplantation, World J Gastroenterol, 22 (2016) 6135-6144.

[8] C.R. Grant, R. Liberal, Liver immunology: How to reconcile tolerance with autoimmunity, Clinics and research in hepatology and gastroenterology, (2016).

[9] R. Bataller, D.A. Brenner, Liver fibrosis, J.Clin.Invest, 115 (2005) 209-218.

[10] C. Trautwein, S.L. Friedman, D. Schuppan, M. Pinzani, Hepatic fibrosis: Concept to treatment, Journal of hepatology, 62 (2015) S15-24.

[11] J. Bruix, K.H. Han, G. Gores, J.M. Llovet, V. Mazzaferro, Liver cancer: Approaching a personalized care, Journal of hepatology, 62 (2015) S144-156.

[12] D. Schuppan, M. Ruehl, R. Somasundaram, E.G. Hahn, Matrix as a modulator of hepatic fibrogenesis, Seminars in liver disease, 21 (2001) 351-372.

[13] R.G. Wells, Cellular sources of extracellular matrix in hepatic fibrosis, Clinics in liver disease, 12 (2008) 759-768, viii.

[14] S.L. Friedman, Molecular regulation of hepatic fibrosis, an integrated cellular response to tissue injury, J.Biol.Chem., 275 (2000) 2247-2250.

[15] A. Geerts, History, heterogeneity, developmental biology, and functions of quiescent hepatic stellate cells, Semin.Liver Dis., 21 (2001) 311-335.

[16] V. Hernandez-Gea, S.L. Friedman, Pathogenesis of liver fibrosis, Annu.Rev.Pathol., 6 (2011) 425456.

[17] J. Guo, S.L. Friedman, Hepatic fibrogenesis, Semin.Liver Dis., 27 (2007) 413-426.

[18] E. Novo, S. Cannito, C. Paternostro, C. Bocca, A. Miglietta, M. Parola, Cellular and molecular mechanisms in liver fibrogenesis, Arch.Biochem.Biophys., 548 (2014) 20-37.

[19] T. Greuter, V.H. Shah, Hepatic sinusoids in liver injury, inflammation, and fibrosis: new pathophysiological insights, J Gastroenterol, 51 (2016) 511-519.

[20] D.A. Brenner, T. Kisseleva, D. Scholten, Y.H. Paik, K. Iwaisako, S. Inokuchi, B. Schnabl, E. Seki, M.S. De, C. Oesterreicher, K. Taura, Origin of myofibroblasts in liver fibrosis, Fibrogenesis. Tissue Repair, 5 Suppl 1 (2012) S17.

[21] T. Kisseleva, The origin of fibrogenic myofibroblasts in fibrotic liver, Hepatology, (2016).

[22] N.C. Henderson, J.P. Iredale, Liver fibrosis: cellular mechanisms of progression and resolution, Clin.Sci.(Lond), 112 (2007) 265-280.

[23] L.C.a.J. Iredale, Matrix Metalloproteinases and Their Inhibitors., in: C.R.G.a.M. Pinzani (Ed.)

Stellate Cells in Health and Disease, Elsevier2015, pp. 107-124.

[24] J.P. Iredale, A. Thompson, N.C. Henderson, Extracellular matrix degradation in liver fibrosis: Biochemistry and regulation, Biochim.Biophys.Acta, 1832 (2013) 876-883.

[25] L.A. Verbruggen, A. Geerts, E. Wisse, C. Lapiere, Serum and synovial fluid antibodies to collagen in rheumatic diseases: a review, Clin.Rheumatol., 5 (1986) 440-444.

[26] Y. Shiratori, T. Ichida, A. Geerts, E. Wisse, Modulation of collagen synthesis by fat-storing cells, isolated from CCl4- or vitamin A-treated rats, Dig.Dis.Sci., 32 (1987) 1281-1289. 
[27] A. Geerts, R. Vrijsen, J. Rauterberg, A. Burt, P. Schellinck, E. Wisse, In vitro differentiation of fatstoring cells parallels marked increase of collagen synthesis and secretion, J.Hepatol., 9 (1989) 59-68. [28] G.J. van Oortmarssen, J.D. Habbema, P.J. van der Maas, H.J. de Koning, H.J. Collette, A.L. Verbeek, A.T. Geerts, K.T. Lubbe, A model for breast cancer screening, Cancer, 66 (1990) 1601-1612. [29] A. Hayasaka, J. Koch, D. Schuppan, W.C. Maddrey, E.G. Hahn, The serum concentrations of the aminoterminal propeptide of procollagen type III and the hepatic content of mRNA for the alpha 1 chain of procollagen type III in carbon tetrachloride-induced rat liver fibrogenesis, J.Hepatol., 13 (1991) 328-338.

[30] A. Geerts, H.J. Geuze, J.W. Slot, B. Voss, D. Schuppan, P. Schellinck, E. Wisse, Immunogold localization of procollagen III, fibronectin and heparan sulfate proteoglycan on ultrathin frozen sections of the normal rat liver, Histochemistry, 84 (1986) 355-362.

[31] D. Schuppan, J.M. Dumont, K.Y. Kim, G. Hennings, E.G. Hahn, Serum concentration of the aminoterminal procollagen type III peptide in the rat reflects early formation of connective tissue in experimental liver cirrhosis, J.Hepatol., 3 (1986) 27-37.

[32] M. Bartneck, K.T. Warzecha, C.G. Tag, S. Sauer-Lehnen, F. Heymann, C. Trautwein, R. Weiskirchen, F. Tacke, Isolation and time lapse microscopy of highly pure hepatic stellate cells, Anal Cell Pathol (Amst), 2015 (2015) 417023.

[33] K. Rombouts, V. Carloni, Determination and characterization of tetraspanin-associated phosphoinositide-4 kinases in primary and neoplastic liver cells., in: M.G. Waugh (Ed.) Lipid Signaling Protocols, Springer Science+Business Media, New York, 2015, pp. 203-212.

[34] I. Mederacke, D.H. Dapito, S. Affo, H. Uchinami, R.F. Schwabe, High-yield and high-purity isolation of hepatic stellate cells from normal and fibrotic mouse livers, Nature protocols, 10 (2015) 305-315.

[35] I. Mederacke, C.C. Hsu, J.S. Troeger, P. Huebener, X. Mu, D.H. Dapito, J.P. Pradere, R.F. Schwabe, Fate tracing reveals hepatic stellate cells as dominant contributors to liver fibrosis independent of its aetiology, Nat.Commun., 4 (2013) 2823.

[36] W.S. Blaner, S.M. O'Byrne, N. Wongsiriroj, J. Kluwe, D.M. D'Ambrosio, H. Jiang, R.F. Schwabe, E.M. Hillman, R. Piantedosi, J. Libien, Hepatic stellate cell lipid droplets: a specialized lipid droplet for retinoid storage, Biochim.Biophys.Acta, 1791 (2009) 467-473.

[37] S.L. Friedman, Hepatic stellate cells: protean, multifunctional, and enigmatic cells of the liver, Physiol Rev., 88 (2008) 125-172.

[38] T. Niki, K. Rombouts, B.P. De, S.K. De, V. Rogiers, D. Schuppan, M. Yoshida, G. Gabbiani, A. Geerts, A histone deacetylase inhibitor, trichostatin $A$, suppresses myofibroblastic differentiation of rat hepatic stellate cells in primary culture, Hepatology, 29 (1999) 858-867.

[39] A. El Taghdouini, M. Najimi, P. Sancho-Bru, E. Sokal, L.A. van Grunsven, In vitro reversion of activated primary human hepatic stellate cells, Fibrogenesis Tissue Repair, 8 (2015) 14.

[40] I. Mannaerts, N.R. Nuytten, V. Rogiers, K. Vanderkerken, L.A. van Grunsven, A. Geerts, Chronic administration of valproic acid inhibits activation of mouse hepatic stellate cells in vitro and in vivo, Hepatology, 51 (2010) 603-614.

[41] M. Pinzani, K. Rombouts, Liver fibrosis: from the bench to clinical targets, Dig.Liver Dis., 36 (2004) 231-242.

[42] Y. Shiratori, A. Geerts, T. Ichida, T. Kawase, E. Wisse, Kupffer cells from CCl4-induced fibrotic livers stimulate proliferation of fat-storing cells, J.Hepatol., 3 (1986) 294-303.

[43] S. De Minicis, E. Seki, H. Uchinami, J. Kluwe, Y. Zhang, D.A. Brenner, R.F. Schwabe, Gene expression profiles during hepatic stellate cell activation in culture and in vivo, Gastroenterology, 132 (2007) 1937-1946.

[44] K. Iwaisako, C. Jiang, M. Zhang, M. Cong, T.J. Moore-Morris, T.J. Park, X. Liu, J. Xu, P. Wang, Y.H. Paik, F. Meng, M. Asagiri, L.A. Murray, A.F. Hofmann, T. lida, C.K. Glass, D.A. Brenner, T. Kisseleva, Origin of myofibroblasts in the fibrotic liver in mice, Proc.Natl.Acad.Sci.U.S.A, (2014).

[45] T. Kisseleva, M. Cong, Y. Paik, D. Scholten, C. Jiang, C. Benner, K. Iwaisako, T. Moore-Morris, B. Scott, H. Tsukamoto, S.M. Evans, W. Dillmann, C.K. Glass, D.A. Brenner, Myofibroblasts revert to an 
inactive phenotype during regression of liver fibrosis, Proc.Natl.Acad.Sci.U.S.A, 109 (2012) 94489453.

[46] J.S. Troeger, I. Mederacke, G.Y. Gwak, D.H. Dapito, X. Mu, C.C. Hsu, J.P. Pradere, R.A. Friedman, R.F. Schwabe, Deactivation of hepatic stellate cells during liver fibrosis resolution in mice, Gastroenterology, 143 (2012) 1073-1083.

[47] A. Mallat, S. Lotersztajn, Reversion of hepatic stellate cell to a quiescent phenotype: From myth to reality?, Journal of hepatology, 59 (2013) 383-386.

[48] N. Milosevic, H. Schawalder, P. Maier, Kupffer cell-mediated differential down-regulation of cytochrome P450 metabolism in rat hepatocytes, Eur.J.Pharmacol., 368 (1999) 75-87.

[49] R. Kostadinova, F. Boess, D. Applegate, L. Suter, T. Weiser, T. Singer, B. Naughton, A. Roth, A long-term three dimensional liver co-culture system for improved prediction of clinically relevant drug-induced hepatotoxicity, Toxicol.Appl.Pharmacol., 268 (2013) 1-16.

[50] A. Gentilini, K. Rombouts, S. Galastri, A. Caligiuri, E. Mingarelli, T. Mello, F. Marra, S. Mantero, M. Roncalli, P. Invernizzi, M. Pinzani, Role of the stromal-derived factor-1 (SDF-1)-CXCR4 axis in the interaction between hepatic stellate cells and cholangiocarcinoma, J.Hepatol., 57 (2012) 813-820.

[51] C. Coulouarn, A. Corlu, D. Glaise, I. Guenon, S.S. Thorgeirsson, B. Clement, Hepatocyte-stellate cell cross-talk in the liver engenders a permissive inflammatory microenvironment that drives progression in hepatocellular carcinoma, Cancer Res., 72 (2012) 2533-2542.

[52] T. Kurokawa, Y.W. Zheng, N. Ohkohchi, Novel functions of platelets in the liver, Journal of gastroenterology and hepatology, 31 (2016) 745-751.

[53] G. Tiegs, A.W. Lohse, Immune tolerance: what is unique about the liver, J Autoimmun, 34 (2010) 1-6.

[54] R. Weiskirchen, F. Tacke, Cellular and molecular functions of hepatic stellate cells in inflammatory responses and liver immunology, Hepatobiliary Surg Nutr, 3 (2014) 344-363.

[55] F. Heymann, F. Tacke, Immunology in the liver--from homeostasis to disease, Nature reviews. Gastroenterology \& hepatology, 13 (2016) 88-110.

[56] S.L. Friedman, M.J. Arthur, Activation of cultured rat hepatic lipocytes by Kupffer cell conditioned medium. Direct enhancement of matrix synthesis and stimulation of cell proliferation via induction of platelet-derived growth factor receptors, J.Clin.Invest, 84 (1989) 1780-1785.

[57] L. Chen, A. Charrier, Y. Zhou, R. Chen, B. Yu, K. Agarwal, H. Tsukamoto, L.J. Lee, M.E. Paulaitis, D.R. Brigstock, Epigenetic regulation of connective tissue growth factor by MicroRNA-214 delivery in exosomes from mouse or human hepatic stellate cells, Hepatology, 59 (2014) 1118-1129.

[58] D. Povero, A. Eguchi, I.R. Niesman, N. Andronikou, d.J. de Mollerat, X, A. Mulya, M. Berk, M. Lazic, S. Thapaliya, M. Parola, H.H. Patel, A.E. Feldstein, Lipid-induced toxicity stimulates hepatocytes to release angiogenic microparticles that require Vanin-1 for uptake by endothelial cells, Sci.Signal., 6 (2013) ra88.

[59] T. Amann, F. Bataille, T. Spruss, M. Muhlbauer, E. Gabele, J. Scholmerich, P. Kiefer, A.K. Bosserhoff, C. Hellerbrand, Activated hepatic stellate cells promote tumorigenicity of hepatocellular carcinoma, Cancer Sci., 100 (2009) 646-653.

[60] Z.M. Wang, L.Y. Zhou, B.B. Liu, Q.A. Jia, Y.Y. Dong, Y.H. Xia, S.L. Ye, Rat hepatic stellate cells alter the gene expression profile and promote the growth, migration and invasion of hepatocellular carcinoma cells, Mol Med Rep, 10 (2014) 1725-1733.

[61] A. Santamato, E. Fransvea, F. Dituri, A. Caligiuri, M. Quaranta, T. Niimi, M. Pinzani, S. Antonaci, G. Giannelli, Hepatic stellate cells stimulate HCC cell migration via laminin-5 production, Clinical science, 121 (2011) 159-168.

[62] A. Azzariti, S. Mancarella, L. Porcelli, A.E. Quatrale, A. Caligiuri, L. Lupo, F. Dituri, G. Giannelli, Hepatic stellate cells induce hepatocellular carcinoma cell resistance to sorafenib through the laminin-332/alpha3 integrin axis recovery of focal adhesion kinase ubiquitination, Hepatology, 64 (2016) 2103-2117. 
[63] A. Mazzocca, V. Carloni, S. Sciammetta, C. Cordella, P. Pantaleo, A. Caldini, P. Gentilini, M. Pinzani, Expression of transmembrane 4 superfamily (TM4SF) proteins and their role in hepatic stellate cell motility and wound healing migration, J.Hepatol., 37 (2002) 322-330.

[64] M. Guvendiren, M. Perepelyuk, R.G. Wells, J.A. Burdick, Hydrogels with differential and patterned mechanics to study stiffness-mediated myofibroblastic differentiation of hepatic stellate cells, J.Mech.Behav.Biomed.Mater., (2013).

[65] A.L. Olsen, B.K. Sackey, C. Marcinkiewicz, D. Boettiger, R.G. Wells, Fibronectin extra domain-A promotes hepatic stellate cell motility but not differentiation into myofibroblasts, Gastroenterology, 142 (2012) 928-937.

[66] J. Heino, The collagen receptor integrins have distinct ligand recognition and signaling functions, Matrix Biol, 19 (2000) 319-323.

[67] L. Chen, D.R. Brigstock, Integrins and heparan sulfate proteoglycans on hepatic stellate cells (HSC) are novel receptors for HSC-derived exosomes, FEBS letters, 590 (2016) 4263-4274.

[68] G. Maheshwari, G. Brown, D.A. Lauffenburger, A. Wells, L.G. Griffith, Cell adhesion and motility depend on nanoscale RGD clustering, Journal of cell science, 113 ( Pt 10) (2000) 1677-1686.

[69] G. Xu, T. Niki, I. Virtanen, V. Rogiers, B.P. De, A. Geerts, Gene expression and synthesis of fibronectin isoforms in rat hepatic stellate cells. Comparison with liver parenchymal cells and skin fibroblasts, J.Pathol., 183 (1997) 90-98.

[70] N. Kawelke, M. Vasel, C. Sens, A. Au, S. Dooley, I.A. Nakchbandi, Fibronectin protects from excessive liver fibrosis by modulating the availability of and responsiveness of stellate cells to active TGF-beta, PLoS.One., 6 (2011) e28181.

[71] N.K. Birukawa, K. Murase, Y. Sato, A. Kosaka, A. Yoneda, H. Nishita, R. Fujita, M. Nishimura, T. Ninomiya, K. Kajiwara, M. Miyazaki, Y. Nakashima, S. Ota, Y. Murakami, Y. Tanaka, K. Minomi, Y. Tamura, Y. Niitsu, Activated Hepatic Stellate Cells Are Dependent on Self-collagen, Cleaved by Membrane Type 1 Matrix Metalloproteinase for Their Growth, J.Biol.Chem., 289 (2014) 2020920221.

[72] T. Saneyasu, R. Akhtar, T. Sakai, Molecular Cues Guiding Matrix Stiffness in Liver Fibrosis, Biomed Res Int, 2016 (2016) 2646212.

[73] S.R. Caliari, M. Perepelyuk, B.D. Cosgrove, S.J. Tsai, G.Y. Lee, R.L. Mauck, R.G. Wells, J.A. Burdick, Stiffening hydrogels for investigating the dynamics of hepatic stellate cell mechanotransduction during myofibroblast activation, Sci Rep, 6 (2016) 21387.

[74] B. Hinz, S.H. Phan, V.J. Thannickal, A. Galli, M.L. Bochaton-Piallat, G. Gabbiani, The myofibroblast: one function, multiple origins, Am.J.Pathol., 170 (2007) 1807-1816.

[75] R. Sakata, T. Ueno, T. Nakamura, H. Ueno, M. Sata, Mechanical stretch induces TGF-beta synthesis in hepatic stellate cells, European journal of clinical investigation, 34 (2004) 129-136. [76] J.W. O'Connor, E.W. Gomez, Biomechanics of TGFbeta-induced epithelial-mesenchymal transition: implications for fibrosis and cancer, Clin Transl Med, 3 (2014) 23.

[77] F. Qi, J.F. Hu, B.H. Liu, C.Q. Wu, H.Y. Yu, D.K. Yao, L. Zhu, MiR-9a-5p regulates proliferation and migration of hepatic stellate cells under pressure through inhibition of Sirt1, World I Gastroenterol, 21 (2015) 9900-9915.

[78] S. Dupont, L. Morsut, M. Aragona, E. Enzo, S. Giulitti, M. Cordenonsi, F. Zanconato, J. Le Digabel, M. Forcato, S. Bicciato, N. Elvassore, S. Piccolo, Role of YAP/TAZ in mechanotransduction, Nature, 474 (2011) 179-183.

[79] I. Mannaerts, S.B. Leite, S. Verhulst, S. Claerhout, N. Eysackers, L.F. Thoen, A. Hoorens, H. Reynaert, G. Halder, L.A. van Grunsven, The Hippo pathway effector YAP controls mouse hepatic stellate cell activation, Journal of hepatology, 63 (2015) 679-688.

[80] J. Shi, C.R. Vakoc, The mechanisms behind the therapeutic activity of BET bromodomain inhibition, Mol Cell, 54 (2014) 728-736.

[81] C.Y. Wang, P. Filippakopoulos, Beating the odds: BETs in disease, Trends Biochem Sci, 40 (2015) 468-479. 
[82] A. Zhubanchaliyev, A. Temirbekuly, K. Kongrtay, L.C. Wanshura, J. Kunz, Targeting Mechanotransduction at the Transcriptional Level: YAP and BRD4 Are Novel Therapeutic Targets for the Reversal of Liver Fibrosis, Front Pharmacol, 7 (2016) 462.

[83] K. Rombouts, V. Carloni, The fibrotic microenvironment as a heterogeneity facet of hepatocellular carcinoma, Fibrogenesis Tissue Repair, 6 (2013) 17.

[84] S.S. Desai, J.C. Tung, V.X. Zhou, J.P. Grenert, Y. Malato, M. Rezvani, R. Espanol-Suner, H. Willenbring, V.M. Weaver, T.T. Chang, Physiological ranges of matrix rigidity modulate primary mouse hepatocyte function in part through hepatocyte nuclear factor 4 alpha, Hepatology, 64 (2016) 261-275.

[85] K. Bhadriraju, C.S. Chen, Engineering cellular microenvironments to improve cell-based drug testing, Drug Discov Today, 7 (2002) 612-620.

[86] S. Breslin, L. O'Driscoll, Three-dimensional cell culture: the missing link in drug discovery, Drug Discov Today, 18 (2013) 240-249.

[87] S. Breslin, L. O'Driscoll, The relevance of using 3D cell cultures, in addition to 2D monolayer cultures, when evaluating breast cancer drug sensitivity and resistance, Oncotarget, 7 (2016) 4574545756.

[88] L.A. Kunz-Schughart, J.P. Freyer, F. Hofstaedter, R. Ebner, The use of 3-D cultures for highthroughput screening: the multicellular spheroid model, J Biomol Screen, 9 (2004) 273-285.

[89] Y. Umezawa, Assay and screening methods for bioactive substances based on cellular signaling pathways, J Biotechnol, 82 (2002) 357-370.

[90] D. Schuppan, M. Pinzani, Anti-fibrotic therapy: lost in translation?, J.Hepatol., 56 Suppl 1 (2012) S66-S74.

[91] S.L. Friedman, Preface. Hepatic fibrosis: pathogenesis, diagnosis, and emerging therapies, Clin.Liver Dis., 12 (2008) xiii-xxiv.

[92] J.L. Horning, S.K. Sahoo, S. Vijayaraghavalu, S. Dimitrijevic, J.K. Vasir, T.K. Jain, A.K. Panda, V. Labhasetwar, 3-D tumor model for in vitro evaluation of anticancer drugs, Molecular pharmaceutics, 5 (2008) 849-862.

[93] V.M. Weaver, S. Lelievre, J.N. Lakins, M.A. Chrenek, J.C. Jones, F. Giancotti, Z. Werb, M.J. Bissell, beta4 integrin-dependent formation of polarized three-dimensional architecture confers resistance to apoptosis in normal and malignant mammary epithelium, Cancer Cell, 2 (2002) 205-216.

[94] N. Shanks, R. Greek, J. Greek, Are animal models predictive for humans?, Philos Ethics Humanit Med, 4 (2009) 2.

[95] A.E. Aitken, T.A. Richardson, E.T. Morgan, Regulation of drug-metabolizing enzymes and transporters in inflammation, Annu Rev Pharmacol Toxicol, 46 (2006) 123-149.

[96] I.A. Freires, J.C. Sardi, R.D. de Castro, P.L. Rosalen, Alternative Animal and Non-Animal Models for Drug Discovery and Development: Bonus or Burden?, Pharm Res, (2016).

[97] E.L. Andrade, A.F. Bento, J. Cavalli, S.K. Oliveira, R.C. Schwanke, J.M. Siqueira, C.S. Freitas, R. Marcon, J.B. Calixto, Non-clinical studies in the process of new drug development - Part II: Good laboratory practice, metabolism, pharmacokinetics, safety and dose translation to clinical studies, Braz J Med Biol Res, 49 (2016) e5646.

[98] E.L. Andrade, A.F. Bento, J. Cavalli, S.K. Oliveira, C.S. Freitas, R. Marcon, R.C. Schwanke, J.M. Siqueira, J.B. Calixto, Non-clinical studies required for new drug development - Part I: early in silico and in vitro studies, new target discovery and validation, proof of principles and robustness of animal studies, Braz J Med Biol Res, 49 (2016) e5644.

[99] D.A. Smith, Species differences in metabolism and pharmacokinetics: are we close to an understanding?, Drug Metab Rev, 23 (1991) 355-373.

[100] N. Shanks, R. Greek, Experimental use of nonhuman primates is not a simple problem, Nature medicine, 14 (2008) 1012; discussion 1012-1013.

[101] R. Edmondson, J.J. Broglie, A.F. Adcock, L. Yang, Three-dimensional cell culture systems and their applications in drug discovery and cell-based biosensors, Assay Drug Dev Technol, 12 (2014) 207-218. 
[102] I. Kola, The state of innovation in drug development, Clin Pharmacol Ther, 83 (2008) 227-230.

[103] J.W. Scannell, A. Blanckley, H. Boldon, B. Warrington, Diagnosing the decline in pharmaceutical R\&D efficiency, Nature reviews. Drug discovery, 11 (2012) 191-200.

[104] M. Hay, D.W. Thomas, J.L. Craighead, C. Economides, J. Rosenthal, Clinical development success rates for investigational drugs, Nat Biotechnol, 32 (2014) 40-51.

[105] J. Arrowsmith, Trial watch: phase III and submission failures: 2007-2010, Nature reviews. Drug discovery, 10 (2011) 87.

[106] J. Shan, D.J. Logan, D.E. Root, A.E. Carpenter, S.N. Bhatia, High-Throughput Platform for Identifying Molecular Factors Involved in Phenotypic Stabilization of Primary Human Hepatocytes In Vitro, J Biomol Screen, 21 (2016) 897-911.

[107] A. Carpentier, I. Nimgaonkar, V. Chu, Y. Xia, Z. Hu, T.J. Liang, Hepatic differentiation of human pluripotent stem cells in miniaturized format suitable for high-throughput screen, Stem Cell Res, 16 (2016) 640-650.

[108] A. Astashkina, B. Mann, D.W. Grainger, A critical evaluation of in vitro cell culture models for high-throughput drug screening and toxicity, Pharmacol Ther, 134 (2012) 82-106.

[109] S.A. Lee, d.Y. No, E. Kang, J. Ju, D.S. Kim, S.H. Lee, Spheroid-based three-dimensional liver-on-achip to investigate hepatocyte-hepatic stellate cell interactions and flow effects, Lab Chip., 13 (2013) 3529-3537.

[110] L.E. O'Brien, M.M. Zegers, K.E. Mostov, Opinion: Building epithelial architecture: insights from three-dimensional culture models, Nat Rev Mol Cell Biol, 3 (2002) 531-537.

[111] Y. Kim, P. Rajagopalan, 3D hepatic cultures simultaneously maintain primary hepatocyte and liver sinusoidal endothelial cell phenotypes, PLoS.One., 5 (2010) e15456.

[112] B.M. Gumbiner, Regulation of cadherin-mediated adhesion in morphogenesis, Nat Rev Mol Cell Biol, 6 (2005) 622-634.

[113] F. Hirschhaeuser, H. Menne, C. Dittfeld, J. West, W. Mueller-Klieser, L.A. Kunz-Schughart, Multicellular tumor spheroids: an underestimated tool is catching up again, J Biotechnol, 148 (2010) 3-15.

[114] C. Hirt, A. Papadimitropoulos, M.G. Muraro, V. Mele, E. Panopoulos, E. Cremonesi, R. Ivanek, E. Schultz-Thater, R.A. Droeser, C. Mengus, M. Heberer, D. Oertli, G. lezzi, P. Zajac, S. EppenbergerCastori, L. Tornillo, L. Terracciano, I. Martin, G.C. Spagnoli, Bioreactor-engineered cancer tissue-like structures mimic phenotypes, gene expression profiles and drug resistance patterns observed "in vivo", Biomaterials, 62 (2015) 138-146.

[115] H. Nagai, K. Terada, G. Watanabe, Y. Ueno, N. Aiba, T. Shibuya, M. Kawagoe, T. Kameda, M. Sato, H. Senoo, T. Sugiyama, Differentiation of liver epithelial (stem-like) cells into hepatocytes induced by coculture with hepatic stellate cells, Biochemical and biophysical research communications, 293 (2002) 1420-1425.

[116] K. Pan, H. Zhou, Z. Zhang, Y. Gao, X. Xu, [Evaluation of co-cultured CL-1 hepatocytes and hepatic stellate cells in rotatory cell culture system], Nan Fang Yi Ke Da Xue Xue Bao, 33 (2013) 902905.

[117] J. Kasuya, R. Sudo, T. Mitaka, M. Ikeda, K. Tanishita, Hepatic stellate cell-mediated threedimensional hepatocyte and endothelial cell triculture model, Tissue Eng Part A, 17 (2011) 361-370. [118] A. Erikson, H.N. Andersen, S.N. Naess, P. Sikorski, L. Davies Cde, Physical and chemical modifications of collagen gels: impact on diffusion, Biopolymers, 89 (2008) 135-143.

[119] E. Brown, T. McKee, E. diTomaso, A. Pluen, B. Seed, Y. Boucher, R.K. Jain, Dynamic imaging of collagen and its modulation in tumors in vivo using second-harmonic generation, Nature medicine, 9 (2003) 796-800.

[120] J. Choi, K. Credit, K. Henderson, R. Deverkadra, Z. He, H. Wiig, H. Vanpelt, M.F. Flessner, Intraperitoneal immunotherapy for metastatic ovarian carcinoma: Resistance of intratumoral collagen to antibody penetration, Clinical cancer research : an official journal of the American Association for Cancer Research, 12 (2006) 1906-1912. 
[121] Y. Song, S.H. Kim, K.M. Kim, E.K. Choi, J. Kim, H.R. Seo, Activated hepatic stellate cells play pivotal roles in hepatocellular carcinoma cell chemoresistance and migration in multicellular tumor spheroids, Sci Rep, 6 (2016) 36750.

[122] M.F. Estrada, S.P. Rebelo, E.J. Davies, M.T. Pinto, H. Pereira, V.E. Santo, M.J. Smalley, S.T. Barry, E.J. Gualda, P.M. Alves, E. Anderson, C. Brito, Modelling the tumour microenvironment in long-term microencapsulated 3D co-cultures recapitulates phenotypic features of disease progression, Biomaterials, 78 (2016) 50-61.

[123] S.B. Leite, T. Roosens, A. El Taghdouini, I. Mannaerts, A.J. Smout, M. Najimi, E. Sokal, F. Noor, C. Chesne, L.A. van Grunsven, Novel human hepatic organoid model enables testing of drug-induced liver fibrosis in vitro, Biomaterials, 78 (2016) 1-10.

[124] M. Larsen, V.V. Artym, J.A. Green, K.M. Yamada, The matrix reorganized: extracellular matrix remodeling and integrin signaling, Curr Opin Cell Biol, 18 (2006) 463-471.

[125] E. Cukierman, R. Pankov, K.M. Yamada, Cell interactions with three-dimensional matrices, Curr Opin Cell Biol, 14 (2002) 633-639.

[126] E. Cukierman, R. Pankov, D.R. Stevens, K.M. Yamada, Taking cell-matrix adhesions to the third dimension, Science, 294 (2001) 1708-1712.

[127] R.O. Hynes, Integrins: bidirectional, allosteric signaling machines, Cell, 110 (2002) 673-687.

[128] J. Qin, O. Vinogradova, E.F. Plow, Integrin bidirectional signaling: a molecular view, PLoS Biol, 2 (2004) e169.

[129] K.R. Legate, R. Fassler, Mechanisms that regulate adaptor binding to beta-integrin cytoplasmic tails, Journal of cell science, 122 (2009) 187-198.

[130] P.P. Provenzano, P.J. Keely, Mechanical signaling through the cytoskeleton regulates cell proliferation by coordinated focal adhesion and Rho GTPase signaling, J.Cell Sci., 124 (2011) 11951205.

[131] J. Schrader, T.T. Gordon-Walker, R.L. Aucott, D.M. van, A. Quaas, S. Walsh, D. Benten, S.J. Forbes, R.G. Wells, J.P. Iredale, Matrix stiffness modulates proliferation, chemotherapeutic response, and dormancy in hepatocellular carcinoma cells, Hepatology, 53 (2011) 1192-1205.

[132] G. Zhao, J. Cui, Q. Qin, J. Zhang, L. Liu, S. Deng, C. Wu, M. Yang, S. Li, C. Wang, Mechanical stiffness of liver tissues in relation to integrin beta1 expression may influence the development of hepatic cirrhosis and hepatocellular carcinoma, J.Surg.Oncol., 102 (2010) 482-489.

[133] R.J. Pelham, Jr., Y.L. Wang, Cell locomotion and focal adhesions are regulated by the mechanical properties of the substrate, Biol Bull, 194 (1998) 348-349; discussion 349-350.

[134] B. Geiger, A. Bershadsky, R. Pankov, K.M. Yamada, Transmembrane crosstalk between the extracellular matrix--cytoskeleton crosstalk, Nat Rev Mol Cell Biol, 2 (2001) 793-805.

[135] Z. Sun, S.S. Guo, R. Fassler, Integrin-mediated mechanotransduction, J Cell Biol, 215 (2016) 445-456.

[136] Y. Hao, A.B. Zerdoum, A.J. Stuffer, A.K. Rajasekaran, X. Jia, Biomimetic Hydrogels Incorporating Polymeric Cell-Adhesive Peptide To Promote the 3D Assembly of Tumoroids, Biomacromolecules, 17 (2016) 3750-3760.

[137] M.J. Bissell, D.C. Radisky, A. Rizki, V.M. Weaver, O.W. Petersen, The organizing principle: microenvironmental influences in the normal and malignant breast, Differentiation, 70 (2002) 537546.

[138] E. Novo, D. Povero, C. Busletta, C. Paternostro, L.V. di Bonzo, S. Cannito, A. Compagnone, A. Bandino, F. Marra, S. Colombatto, E. David, M. Pinzani, M. Parola, The biphasic nature of hypoxiainduced directional migration of activated human hepatic stellate cells, The Journal of pathology, 226 (2012) 588-597.

[139] Y. Jin, Y. Bai, H. Ni, L. Qiang, L. Ye, Y. Shan, M. Zhou, Activation of autophagy through calciumdependent AMPK/mTOR and PKCtheta pathway causes activation of rat hepatic stellate cells under hypoxic stress, FEBS letters, 590 (2016) 672-682.

[140] T. Kaully, K. Kaufman-Francis, A. Lesman, S. Levenberg, Vascularization--the conduit to viable engineered tissues, Tissue Eng Part B Rev, 15 (2009) 159-169. 
[141] L.G. Griffith, M.A. Swartz, Capturing complex 3D tissue physiology in vitro, Nat Rev Mol Cell Biol, 7 (2006) 211-224.

[142] K. Kellner, G. Liebsch, I. Klimant, O.S. Wolfbeis, T. Blunk, M.B. Schulz, A. Gopferich, Determination of oxygen gradients in engineered tissue using a fluorescent sensor, Biotechnol Bioeng, 80 (2002) 73-83.

[143] N. Tsamandouras, T. Kostrzewski, C.L. Stokes, L.G. Griffith, D.J. Hughes, M. Cirit, Quantitative Assessment of Population Variability in Hepatic Drug Metabolism Using a Perfused Three-

Dimensional Human Liver Microphysiological System, The Journal of pharmacology and experimental therapeutics, 360 (2017) 95-105.

[144] K. Domansky, W. Inman, J. Serdy, A. Dash, M.H. Lim, L.G. Griffith, Perfused multiwell plate for 3D liver tissue engineering, Lab Chip, 10 (2010) 51-58.

[145] T. Kostrzewski, Fully human 3D cell culture model of non-alcoholic steatohepatitis, Hepatology, 63 (2016) 765A.

[146] K. Kim, K. Ohashi, R. Utoh, K. Kano, T. Okano, Preserved liver-specific functions of hepatocytes in 3D co-culture with endothelial cell sheets, Biomaterials, 33 (2012) 1406-1413.

[147] D. Yoon No, K.H. Lee, J. Lee, S.H. Lee, 3D liver models on a microplatform: well-defined culture, engineering of liver tissue and liver-on-a-chip, Lab Chip, 15 (2015) 3822-3837.

[148] S.A. Lee, Y. No da, E. Kang, J. Ju, D.S. Kim, S.H. Lee, Spheroid-based three-dimensional liver-ona-chip to investigate hepatocyte-hepatic stellate cell interactions and flow effects, Lab Chip, 13 (2013) 3529-3537.

[149] H. Senoo, K. Imai, Y. Matano, M. Sato, Molecular mechanisms in the reversible regulation of morphology, proliferation and collagen metabolism in hepatic stellate cells by the three-dimensional structure of the extracellular matrix, J.Gastroenterol.Hepatol., 13 Suppl (1998) S19-S32.

[150] M. Miura, M. Sato, I. Toyoshima, H. Senoo, Extension of long cellular processes of hepatic stellate cells cultured on extracellular type I collagen gel by microtubule assembly: observation utilizing time-lapse video-microscopy, Cell Struct.Funct., 22 (1997) 487-492.

[151] K. Imai, T. Sato, H. Senoo, Adhesion between cells and extracellular matrix with special reference to hepatic stellate cell adhesion to three-dimensional collagen fibers, Cell Struct.Funct., 25 (2000) 329-336.

[152] R. Awata, H. Sawai, K. Imai, K. Terada, H. Senoo, T. Sugiyama, Morphological comparison and functional reconstitution of rat hepatic parenchymal cells on various matrices, J.Gastroenterol.Hepatol., 13 Suppl (1998) S55-S61.

[153] J. Landry, D. Bernier, C. Ouellet, R. Goyette, N. Marceau, Spheroidal aggregate culture of rat liver cells: histotypic reorganization, biomatrix deposition, and maintenance of functional activities, J Cell Biol, 101 (1985) 914-923.

[154] E. Fennema, N. Rivron, J. Rouwkema, C. van Blitterswijk, J. de Boer, Spheroid culture as a tool for creating 3D complex tissues, Trends Biotechnol, 31 (2013) 108-115.

[155] R.M. Tostoes, S.B. Leite, M. Serra, J. Jensen, P. Bjorquist, M.J. Carrondo, C. Brito, P.M. Alves, Human liver cell spheroids in extended perfusion bioreactor culture for repeated-dose drug testing, Hepatology, 55 (2012) 1227-1236.

[156] A. Kobayashi, M. Goto, T. Sekine, A. Masumoto, N. Yamamoto, K. Kobayashi, T. Akaike, Regulation of differentiation and proliferation of rat hepatocytes by lactose-carrying polystyrene, Artif Organs, 16 (1992) 564-567.

[157] M. Drewitz, M. Helbling, N. Fried, M. Bieri, W. Moritz, J. Lichtenberg, J.M. Kelm, Towards automated production and drug sensitivity testing using scaffold-free spherical tumor microtissues, Biotechnol J, 6 (2011) 1488-1496.

[158] Y. Jun, A.R. Kang, J.S. Lee, G.S. Jeong, J. Ju, D.Y. Lee, S.H. Lee, 3D co-culturing model of primary pancreatic islets and hepatocytes in hybrid spheroid to overcome pancreatic cell shortage,

Biomaterials, 34 (2013) 3784-3794. 
[159] C. Chen, F. Loe, A. Blocki, Y. Peng, M. Raghunath, Applying macromolecular crowding to enhance extracellular matrix deposition and its remodeling in vitro for tissue engineering and cellbased therapies, Adv Drug Deliv Rev, 63 (2011) 277-290.

[160] C.Z. Chen, Y.X. Peng, Z.B. Wang, P.V. Fish, J.L. Kaar, R.R. Koepsel, A.J. Russell, R.R. Lareu, M. Raghunath, The Scar-in-a-Jar: studying potential antifibrotic compounds from the epigenetic to extracellular level in a single well, Br.J.Pharmacol., 158 (2009) 1196-1209.

[161] K.M. Hakkinen, J.S. Harunaga, A.D. Doyle, K.M. Yamada, Direct comparisons of the morphology, migration, cell adhesions, and actin cytoskeleton of fibroblasts in four different threedimensional extracellular matrices, Tissue Eng Part A, 17 (2011) 713-724.

[162] J.S. Harunaga, K.M. Yamada, Cell-matrix adhesions in 3D, Matrix Biol., 30 (2011) 363-368.

[163] I.M. Westra, D. Oosterhuis, G.M. Groothuis, P. Olinga, Precision-cut liver slices as a model for the early onset of liver fibrosis to test antifibrotic drugs, Toxicol.Appl.Pharmacol., 274 (2014) 328338.

[164] E. Szalowska, G. Stoopen, M.J. Groot, P.J. Hendriksen, A.A. Peijnenburg, Treatment of mouse liver slices with cholestatic hepatotoxicants results in down-regulation of Fxr and its target genes, BMC.Med.Genomics, 6 (2013) 39.

[165] S. Vatakuti, P. Olinga, J.L. Pennings, G.M. Groothuis, Validation of precision-cut liver slices to study drug-induced cholestasis: a transcriptomics approach, Arch Toxicol, (2016).

[166] R.P. van Swelm, M. Hadi, C.M. Laarakkers, R. Masereeuw, G.M. Groothuis, F.G. Russel, Proteomic profiling in incubation medium of mouse, rat and human precision-cut liver slices for biomarker detection regarding acute drug-induced liver injury, J.Appl.Toxicol., (2013).

[167] P. Olinga, K. Groen, I.H. Hof, K.R. De, H.J. Koster, W.R. Leeman, A.A. Rutten, T.K. Van, G.M. Groothuis, Comparison of five incubation systems for rat liver slices using functional and viability parameters, J.Pharmacol.Toxicol.Methods, 38 (1997) 59-69.

[168] P. Olinga, D. Schuppan, Precision-cut liver slices: a tool to model the liver ex vivo, J.Hepatol., 58 (2013) 1252-1253.

[169] M. van de Bovenkamp, G.M. Groothuis, A.L. Draaisma, M.T. Merema, J.I. Bezuijen, M.J. van Gils, D.K. Meijer, S.L. Friedman, P. Olinga, Precision-cut liver slices as a new model to study toxicityinduced hepatic stellate cell activation in a physiologic milieu, Toxicol.Sci., 85 (2005) 632-638. [170] H. Clouzeau-Girard, C. Guyot, C. Combe, V. Moronvalle-Halley, C. Housset, T. Lamireau, J. Rosenbaum, A. Desmouliere, Effects of bile acids on biliary epithelial cell proliferation and portal fibroblast activation using rat liver slices, Lab Invest, 86 (2006) 275-285.

[171] C. Guyot, S. Lepreux, C. Combe, V. Sarrazy, F. Billet, C. Balabaud, P. Bioulac-Sage, A.

Desmouliere, Fibrogenic cell phenotype modifications during remodelling of normal and pathological human liver in cultured slices, Liver Int., 30 (2010) 1529-1540.

[172] A.E. Vickers, M. Saulnier, E. Cruz, M.T. Merema, K. Rose, P. Bentley, P. Olinga, Organ slice viability extended for pathway characterization: an in vitro model to investigate fibrosis, Toxicol.Sci., 82 (2004) 534-544.

[173] T. Sasagawa, T. Shimizu, M. Yamato, T. Okano, Endothelial colony-forming cells for preparing prevascular three-dimensional cell-dense tissues using cell-sheet engineering, J Tissue Eng Regen Med, 10 (2016) 739-747.

[174] K. Kim, R. Utoh, K. Ohashi, T. Kikuchi, T. Okano, Fabrication of functional 3D hepatic tissues with polarized hepatocytes by stacking endothelial cell sheets in vitro, J Tissue Eng Regen Med, (2015).

[175] Y. Tsuda, A. Kikuchi, M. Yamato, A. Nakao, Y. Sakurai, M. Umezu, T. Okano, The use of patterned dual thermoresponsive surfaces for the collective recovery as co-cultured cell sheets, Biomaterials, 26 (2005) 1885-1893.

[176] V. Liu Tsang, A.A. Chen, L.M. Cho, K.D. Jadin, R.L. Sah, S. DeLong, J.L. West, S.N. Bhatia, Fabrication of 3D hepatic tissues by additive photopatterning of cellular hydrogels, FASEB journal : official publication of the Federation of American Societies for Experimental Biology, 21 (2007) 790801. 
[177] M. Rimann, U. Graf-Hausner, Synthetic 3D multicellular systems for drug development, Curr Opin Biotechnol, 23 (2012) 803-809.

[178] J.P. Miranda, A. Rodrigues, R.M. Tostoes, S. Leite, H. Zimmerman, M.J. Carrondo, P.M. Alves, Extending hepatocyte functionality for drug-testing applications using high-viscosity alginateencapsulated three-dimensional cultures in bioreactors, Tissue Eng Part C Methods, 16 (2010) 12231232.

[179] M. Janiak, H.R. Hashmi, A. Janowska-Wieczorek, Use of the Matrigel-based assay to measure the invasiveness of leukemic cells, Exp Hematol, 22 (1994) 559-565.

[180] A.D. Celiz, J.G. Smith, R. Langer, D.G. Anderson, D.A. Winkler, D.A. Barrett, M.C. Davies, L.E. Young, C. Denning, M.R. Alexander, Materials for stem cell factories of the future, Nat Mater, 13 (2014) 570-579.

[181] A. Skardal, L. Smith, S. Bharadwaj, A. Atala, S. Soker, Y. Zhang, Tissue specific synthetic ECM hydrogels for 3-D in vitro maintenance of hepatocyte function, Biomaterials, 33 (2012) 4565-4575. [182] L. Frenguelli, Development of Human Liver Extracellular Matrix Hydrogel for Three Dimensional Cell Culture and Cell Transplantation, Hepatology, 63 (2016) 27A.

[183] G. Mazza, K. Rombouts, A. Rennie Hall, L. Urbani, T. Vinh Luong, W. Al-Akkad, L. Longato, D. Brown, P. Maghsoudlou, A.P. Dhillon, B. Fuller, B. Davidson, K. Moore, D. Dhar, P. De Coppi, M. Malago, M. Pinzani, Decellularized human liver as a natural 3D-scaffold for liver bioengineering and transplantation, Sci Rep, 5 (2015) 13079.

[184] G. Mazza, J.P. Simons, R. Al-Shawi, S. Ellmerich, L. Urbani, S. Giorgetti, G.W. Taylor, J.A. Gilbertson, A.R. Hall, W. Al-Akkad, D. Dhar, P.N. Hawkins, P. De Coppi, M. Pinzani, V. Bellotti, P.P. Mangione, Amyloid persistence in decellularized liver: biochemical and histopathological characterization, Amyloid, 23 (2016) 1-7.

[185] P. Maghsoudlou, F. Georgiades, H. Smith, A. Milan, P. Shangaris, L. Urbani, S.P. Loukogeorgakis, B. Lombardi, G. Mazza, C. Hagen, N.J. Sebire, M. Turmaine, S. Eaton, A. Olivo, J. Godovac-

Zimmermann, M. Pinzani, P. Gissen, P. De Coppi, Optimization of Liver Decellularization Maintains Extracellular Matrix Micro-Architecture and Composition Predisposing to Effective Cell Seeding, PloS one, 11 (2016) e0155324.

[186] P.M. Crapo, T.W. Gilbert, S.F. Badylak, An overview of tissue and whole organ decellularization processes, Biomaterials, 32 (2011) 3233-3243.

[187] B.E. Uygun, A. Soto-Gutierrez, H. Yagi, M.L. Izamis, M.A. Guzzardi, C. Shulman, J. Milwid, N. Kobayashi, A. Tilles, F. Berthiaume, M. Hertl, Y. Nahmias, M.L. Yarmush, K. Uygun, Organ reengineering through development of a transplantable recellularized liver graft using decellularized liver matrix, Nature medicine, 16 (2010) 814-820.

[188] P.M. Baptista, M.M. Siddiqui, G. Lozier, S.R. Rodriguez, A. Atala, S. Soker, The use of whole organ decellularization for the generation of a vascularized liver organoid, Hepatology, 53 (2011) 604-617.

[189] J.S. Lee, J. Shin, H.M. Park, Y.G. Kim, B.G. Kim, J.W. Oh, S.W. Cho, Liver extracellular matrix providing dual functions of two-dimensional substrate coating and three-dimensional injectable hydrogel platform for liver tissue engineering, Biomacromolecules, 15 (2014) 206-218.

[190] A. Telese, Extracellular Matrix Scaffolds Obtained from Human Normal or Cirrhotic Liver as Novel Platforms to Investigate The Biology of Liver Cancer Cells, Hepatology, 63 (2016) 167A.

[191] Q. Li, B.E. Uygun, S. Geerts, S. Ozer, M. Scalf, S.E. Gilpin, H.C. Ott, M.L. Yarmush, L.M. Smith, N.V. Welham, B.L. Frey, Proteomic analysis of naturally-sourced biological scaffolds, Biomaterials, 75 (2016) 37-46.

[192] M. Romero-Lopez, A.L. Trinh, A. Sobrino, M.M. Hatch, M.T. Keating, C. Fimbres, D.E. Lewis, P.D. Gershon, E.L. Botvinick, M. Digman, J.S. Lowengrub, C.C. Hughes, Recapitulating the human tumor microenvironment: Colon tumor-derived extracellular matrix promotes angiogenesis and tumor cell growth, Biomaterials, 116 (2017) 118-129.

[193] G. Mazza, L. Longato, W. Al-Akkad, A. Telese, L. Urbani, A.R. Hall, B. Robinson, L. Frenguelli, O. Willacy, M. Curti, Engineering Healthy And Cirrhotic Human Liver Matrix: A New 3D Platform For 
Investigating Liver Cirrhosis And HCC, HEPATOLOGY, WILEY-BLACKWELL 111 RIVER ST, HOBOKEN 07030-5774, NJ USA, 2015, pp. 889A-890A.

[194] G. Mazza, W. Al-Akkad, L. Longato, A. Telese, A.R. Hall, L. Urbani, B. Robinson, G. Marrone, O. Willacy, L. Frenguelli, Three-dimensional bioactive human liver acellular scaffold with preserved architecture and biomechanical properties, Hepatology, 62 (2015) 381A-382A.

[195] B. Yang, Y. Zhang, L. Zhou, Z. Sun, J. Zheng, Y. Chen, Y. Dai, Development of a porcine bladder acellular matrix with well-preserved extracellular bioactive factors for tissue engineering, Tissue Eng Part C Methods, 16 (2010) 1201-1211.

[196] M. Caralt, J.S. Uzarski, S. lacob, K.P. Obergfell, N. Berg, B.M. Bijonowski, K.M. Kiefer, H.H. Ward, A. Wandinger-Ness, W.M. Miller, Z.J. Zhang, M.M. Abecassis, J.A. Wertheim, Optimization and critical evaluation of decellularization strategies to develop renal extracellular matrix scaffolds as biological templates for organ engineering and transplantation, Am J Transplant, 15 (2015) 64-75. [197] S.N. Bhatia, G.H. Underhill, K.S. Zaret, I.J. Fox, Cell and tissue engineering for liver disease, Sci.Transl.Med., 6 (2014) 245sr242.

[198] J. Kasuya, R. Sudo, T. Mitaka, M. Ikeda, K. Tanishita, Spatio-temporal control of hepatic stellate cell-endothelial cell interactions for reconstruction of liver sinusoids in vitro, Tissue Eng Part A, 18 (2012) 1045-1056. 